\title{
CORRELATIONS BETWEEN CLUSTER DIFFERENTIATION 4 COUNTS, HUMAN \\ IMMUNODEFICIENCY VIRUS CLINICAL STAGES, AND HEMOGLOBIN LEVEL AMONG HUMAN IMMUNODEFICIENCY VIRUS PATIENTS WITH ANEMIA IN MERPATI CLINIC, WANGAYA HOSPITAL, DENPASAR, BALI, INDONESIA: A CROSS-SECTIONAL STUDY
}

\section{KETUT SURYANA ${ }^{1}$, HAMONG SUHARSONO ${ }^{2}$, GEDE BUDIASA ${ }^{3}$, JARWA ANTARA ${ }^{4}$, PUJI ASTUTI ${ }^{1}$, IDA AYU INDAH ${ }^{1}$, PUTRI STUTI ${ }^{1}$}

${ }^{1}$ Department of Internal Medicine, Wangaya HIV Study Group, Merpati Clinic, Wangaya Hospital, Denpasar, Indonesia. ${ }^{2}$ Department of Biochemistry, Veterinary Faculty of Udayana University of Denpasar Indonesia. ${ }^{3}$ Department of Clinical Pathology, Wangaya Hospital, Denpasar, Indonesia. ${ }^{4}$ Department of Internal Medicine, Medical Faculty of Udayana, University-Sanglah Hospital, Denpasar, Indonesia. Email: ketutsuryana@gmail.com

Received: 16 November 2018, Revised and Accepted: 05 January 2018

ABSTRACT

Objective: The objective of this study was to determine the correlation between cluster of differentiation 4 (CD4) counts, human immunodeficiency virus (HIV) clinical stages, and hemoglobin (Hb) level among HIV-infected patients with anemia.

Methods: A cross-sectional study was conducted in November 2017 at Merpati Clinic of Wangaya Hospital, Denpasar, Bali, Indonesia. We selected 79 HIV patients with anemia to participate in our study. We grouped CD 4 counts into two categories: $<200$ cells/ $\mu \mathrm{L}$ and $\geq 200$ cells $/ \mu \mathrm{L}$, and we classified the HIV clinical stages into HIV and acquired immunodeficiency syndrome (AIDS).

Results: About 55.7\% (44) of men and 44.3\% (35) of women were participated in this study. As many as, 91.1\% (72) of participants were AIDS patients. The mean $\mathrm{Hb}$ was $8.77 \mathrm{~g} / \mathrm{dl}$ with SD $1.79 \mathrm{~g} / \mathrm{dl} .81 \%$ (64) of study participants were suffered from anemia on chronic disease or inflammatory anemia, and 19\% (15) of study participants were suffered from iron deficiency anemia. The median for CD4 counts was 94 cells $/ \mu \mathrm{L}(3-309$ cells $/ \mu \mathrm{L})$ with as many as $78.5 \%(62)$ of participants were found to have low CD4 counts $(<200$ cells $/ \mu \mathrm{L})$. Spearman analysis revealed a positive correlation between $\mathrm{CD} 4$ counts and $\mathrm{Hb}$ level $(\mathrm{r}=0.427, \mathrm{p}<0.001)$. Independent sample t-test analysis found a correlation between the HIV clinical stages and $\mathrm{Hb}$ level. There was a difference between the mean of $\mathrm{Hb}$ level in each stage with the average difference of $0.8 \mathrm{~g} / \mathrm{dl}(95 \%$ confidence interval $0.04-1.6$; $\mathrm{p}<0.04)$.

Conclusions: There is a correlation between CD4 counts, HIV clinical stages, and Hb level among HIV patients with anemia.

Keywords: Human immunodeficiency virus clinical stages, Cluster differentiation 4 counts, Anemia.

(c) 2019 The Authors. Published by Innovare Academic Sciences Pvt Ltd. This is an open access article under the CC BY license (http://creativecommons. org/licenses/by/4. 0/) DOI: http://dx.doi.org/10.22159/ajpcr.2019.v12i3.30794

\section{INTRODUCTION}

Anemia is the most common hematologic disorder associated with human immunodeficiency virus (HIV) infection affecting $60-80 \%$ of patients in the late stages of HIV at various cluster of differentiation 4 (CD4) levels and with various causes [1-3].

The pathophysiology of HIV-related anemia involves three basic mechanisms, which are decreased red blood cell production, increased red blood cell destruction, and ineffective production of red blood cells. Anemia can also be a result of nutritional deficiency, most commonly iron, folic acid, and Vitamin B12. Vitamin B12 deficiency is associated with malabsorption in the ileum or due to gastric pathological processes caused by infections affecting the gastric mucosa in patients with HIV [4-6].

Although anemia can occur in any stages of HIV infection, its severity positively correlates with progression of the disease and mortality [7].

Owiredu et al. reported that highly active antiretroviral therapy can increase B12 serum level; however, they do not describe symptoms associated with B12 deficiency such as macroscopic anemia and neuropathy. Anemia independently decreases the survival of the patient (HR 2.6, 95\% confidence interval [CI] 1.9-3.4), improves disease progression, and increases mortality in HIV-infected individuals [6,8-29].
The incidence of anemia increases annually with the progression of the disease, affecting $3 \%$ of all asymptomatic HIV infection patients, $12 \%$ of asymptomatic patients with $\mathrm{CD} 4<200 / \mu \mathrm{L}$, and $37 \%$ of patients with acquired immunodeficiency syndrome (AIDS). The risk of anemia increases in African-American race, older age, low body mass index, history of pneumonia, oral candidiasis, history of fever, use of zidovudine (ZDV), low CD4 cell counts, and high HIV-1 RNA levels in plasma. ZDV was reported as a cause of hematological disorders, especially, anemia at weeks 4-12 of ZDV initiation [11-21,30-47].

The causes of anemia in HIV patients are multifactorial, such as the HIV itself, opportunistic infection, immune mechanisms, malignancies, and drugs. Nutritional anemia in HIV patients due to an inadequate diet intake and malabsorption. High viremia, decreased CD4 counts, and severity of anemia (lower hemoglobin $[\mathrm{Hb}]$ levels) are associated with increased morbidity and mortality in HIV-infected patients $[3,7,8,11,14]$.

This study was to evaluate the correlation of anemia to CD4 counts and HIV clinical stages in HIV patients were visited to Merpati Clinic, Wangaya hospital, Denpasar, Bali, Indonesia.

\section{METHODS}

A cross-sectional study was conducted in November 2017 at Merpati Clinic of Wangaya Hospital, Denpasar, Bali. Ethical clearance was 
obtained No: 05/RSUDW/Litbang/2017 from the local ethical committees. We collected data from a patient who visited Merpati Clinic and completed at least 1 year follow-up from the ethical clearance granted date.

\section{Research purposes}

This study aimed to determine the correlations between CD4 counts, HIV clinical stages, and Hb level among HIV patients with anemia.

\section{Research design}

A cross-sectional study was conducted at Merpati Clinic, Wangaya Hospital, Denpasar, Bali-Indonesia. We recruited 79 HIV patients with various stages of anemia.

\section{Population and duration of the study}

The study participants were HIV patient with various stages of anemia visiting the outpatient services of Merpati Clinic, Wangaya Hospital, Denpasar, Bali, Indonesia. The participants were aged between 18 and 65 years old. The study was conducted in November 2017.

\section{Sample size}

Using a consecutive sampling technique, we included a total of 79 patients. Every patient who met the criteria was selected until we reached the desired sample size. The inclusion criteria included HIV patients with anemia, aged over 18 years old. We excluded pregnant and lactating women, patients with chronic renal impairment, and patients with thalassemia.

\section{Variables and data sources}

Our study variables included CD4 counts, HIV clinical stages, and $\mathrm{Hb}$ levels. We also collected data on social demographic characteristics such as age, sex, and other laboratory parameters.

\section{Data analysis}

We used a structured questionnaire to obtain data on sociodemographic characteristics. The HIV clinical stages of all participants were determined using the World Health Organization (WHO) guideline and were grouped as clinical HIV and advanced clinical form of AIDS.

CD4 parameters were measured following the recommended guideline and were grouped into two categories: CD4 $\geq 200$ cells $/ \mu \mathrm{L}$ and $<200$ cells $/ \mu \mathrm{L}$. Hb level was obtained from routine hematology test and was grouped into four groups: Mild anemia ( $\mathrm{Hb}: 10-11.9 \mathrm{~g} / \mathrm{dl}$ ), moderate anemia (Hb: 9.9-7 g/dl), severe anemia (Hb: 6.9-4 g/dl), and very severe anemia ( $\mathrm{Hb}: 4 \mathrm{~g} / \mathrm{dl})$.

We displayed the average and standard deviation for all numerical or continuous variables. However, we used median and interquartile range for all data that were not normally distributed. Categorical data were presented in relative frequency (number and percent). We performed the non-parametric analysis to determine correlations of each independent variable with $\mathrm{Hb}$ level. We used the precision value of $95 \%(\mathrm{p}<0.05)$. All data analysis was performed using SPSS software for Windows version 24.0 .

\section{RESULTS}

A total of 79 individuals with HIV infection in various stages of anemia were participated in this study. The sociodemographic characteristics are presented in Table 2 .

The WHO defines anemia as Hb level under $13 \mathrm{~g} / \mathrm{dl}$ for men and under $12 \mathrm{~g} / \mathrm{dl}$ for women. For the purpose of this study, we used the classification as depicted in Table 1 [6].

The age data were not normally distributed when tested using the Kolmogorov-Smirnov test. The median of age data for all participants was 37 years old, with the youngest of 20 years old and the oldest of 75 years old. The body mass index was normally distributed with a mean of $18.65 \mathrm{~kg} / \mathrm{m}^{2}\left(\mathrm{SD} \pm 2.86 \mathrm{~kg} / \mathrm{m}^{2}\right)$. The overall CD4 counts of the participants were not normally distributed. The median of CD4 counts of all participants was 94 cells $/ \mu \mathrm{L}$ with the lowest of 3 cells $/ \mu \mathrm{L}$ and the

Table 1: Staging of anemia severity [6]

\begin{tabular}{ll}
\hline Anemia severity & Hb $(\mathrm{g} / \mathbf{d} \mathbf{l})$ \\
\hline Mild & $10-11.9$ \\
Moderate & $9.9-7$ \\
Severe & $6.9-4$ \\
Very severe & $<4$ \\
\hline
\end{tabular}

Table 2: The sociodemographic characteristics of participants (sex, education, marital status, anemia morphology, anemia severity, HIV severity, and opportunistic infection)

\begin{tabular}{|c|c|}
\hline Variables & n (\%) \\
\hline \multicolumn{2}{|l|}{ Sex } \\
\hline Male & $44(55.7)$ \\
\hline Female & $35(44.3)$ \\
\hline \multicolumn{2}{|l|}{ Education } \\
\hline Non-formal education & $2(2.5)$ \\
\hline Elementary school & $6(7.6)$ \\
\hline Junior high school & $19(24.1)$ \\
\hline High school & $45(57.0)$ \\
\hline University & $7(8.9)$ \\
\hline \multicolumn{2}{|l|}{ Marital status } \\
\hline Marriage & $60(75.9)$ \\
\hline Single & $11(13.9)$ \\
\hline Widow/widower & $8(10.1)$ \\
\hline \multicolumn{2}{|l|}{ Anemia morphology } \\
\hline ACD & $64(81.0)$ \\
\hline IDA & $15(19.0)$ \\
\hline \multicolumn{2}{|l|}{ Anemia severity } \\
\hline Mild & $20(25.3)$ \\
\hline Moderate & $47(59.5)$ \\
\hline Severe & $10(12.7)$ \\
\hline Very severe & $2(2.5)$ \\
\hline \multicolumn{2}{|l|}{ CD4 lymphocyte count (Cells/ $\mu \mathrm{L})$} \\
\hline$<200$ & $62(78.5)$ \\
\hline$\geq 200$ & $17(21.5)$ \\
\hline \multicolumn{2}{|l|}{ Chest X-ray } \\
\hline Normal & $19(24.1)$ \\
\hline Tuberculosis and/or pneumonia & $60(75.9)$ \\
\hline \multicolumn{2}{|l|}{ Stage of HIV } \\
\hline HIV & $7(8.9)$ \\
\hline AIDS & $72(91.1)$ \\
\hline \multicolumn{2}{|l|}{ Opportunistic infection } \\
\hline Without opportunistic infection & $8(10.1)$ \\
\hline With opportunistic infection & $71(89.9)$ \\
\hline
\end{tabular}

Table 3: Participants' characteristic (age, height, weight, BMI and hematologic data)

\begin{tabular}{|c|c|}
\hline Characteristic & Mean $\pm S D /$ median (minimum-maximum) \\
\hline Age (year) & $37(20-75)$ \\
\hline Height (cm) & $160(148-185)$ \\
\hline Weight (kg) & $50(30-78)$ \\
\hline BMI $\left(\mathrm{kg} / \mathrm{m}^{2}\right)$ & $18.65 \pm 2.86$ \\
\hline \multicolumn{2}{|l|}{ Hematologic data } \\
\hline $\mathrm{Hb}(\mathrm{g} / \mathrm{dl})$ & $8.77 \pm 1.79$ \\
\hline $\mathrm{SI}(\mathrm{mg} / \mathrm{L})$ & $42(7-187)$ \\
\hline TIBC $(\mathrm{mg} / \mathrm{mL})$ & $104(37-602)$ \\
\hline Ferritin $(\mu \mathrm{g} / \mathrm{ml})$ & 425 (16-678) \\
\hline Lymphocyte (\%) & $14.1(1.7-41.4)$ \\
\hline CD 4 counts (cells $/ \mu \mathrm{L})$ & $94(3-309)$ \\
\hline
\end{tabular}

$\mathrm{n}=79$, Values are numbers or numbers (range). Data are expressed as mean \pm SD. SD: Standard deviation, Hb: Hemoglobin, BMI: Body mass index, CD4: Cluster of differentiation 4, SI: Serum iron, TIBC: Total iron binding capacity 
highest of 309 cells $/ \mu \mathrm{L}$. The Hb levels of all participants were normally distributed with mean values of $8.77 \mathrm{~g} / \mathrm{dl}(\mathrm{SD} \pm 1.79 \mathrm{~g} / \mathrm{dl}$ (Table 3)

\section{Correlation between CD4 counts and $\mathrm{Hb}$ levels}

Due to the CD4 counts, data were not normally distributed, and we performed a non-parametric correlation (Spearman) analysis to determine the correlation between CD4 counts and Hb level (Table 4).

The relationship between clinical stage and $\mathrm{Hb}$ levels

Independent sample t-test was performed to assess the relationship between HIV clinical stages and Hb levels (Table 5).

\section{DISCUSSION}

\section{Correlation between CD4 counts and Hb levels}

Anemia is one of the most common abnormalities seen in HIV. The severity of anemia correlates with the late clinical HIV stage and low CD4 counts. An increased number of viruses along with the development of HIV was followed by the release of inflammatory cytokines such as tumor necrosis factor (TNF), interleukin-1, and interferon gamma. The cytokines have been shown to inhibit red cell production (erythropoiesis) and myelosuppression. TNF levels were found to be consistently elevated in HIV infection, and this condition is correlated with viral load. As HIV disease progresses, the severity of anemia also increases $[12,17,23,27,31-41]$

This study found a moderate positive correlation between CD4 counts and $\mathrm{Hb}$ level $(\mathrm{r}=0.427 ; \mathrm{p}<0.001)$.

Obirikorang and Yeboah, 2009, in a prospective case-control study involving 228 individuals with HIV in Ghana, also found a positive correlation between Hb levels and CD4 counts ( $r=0.1755$; $p<0.0001)$ [22].

$\mathrm{Hb}$ is an easy and cheap parameter that can be used to predict morbidity and mortality of a progression of HIV infection. Hb monitoring can alert clinicians regarding anemia conditions of HIV patients and to determine anemia treatments required or not.

Similar studies by Paras et al., 2017, found that low CD4 counts were significantly associated with anemia $(p=0.0001)[23,29,30,42]$.

Moore et al., 1998, found that anemia therapy using erythropoietin was associated with improved prognosis allowing a long-term administration of ZDV.

Table 4: Correlation between CD4 counts and Hb levels

\begin{tabular}{llll}
\hline Variables & Mean \pm SD (minimum-maximum) & $\mathbf{r}$ & p-value \\
\hline CD4 counts & $94(3-309)$ cell $/ \mu \mathrm{L}$ & 0.427 & $<0.001^{* *}$ \\
Hb levels & $8.8 \pm 1.8 \mathrm{~g} / \mathrm{dl}$ & & \\
\hline
\end{tabular}

$\mathrm{n}=79$, Values are numbers or numbers (range). Data are expressed as mean \pm SD. SD: Standard deviation, $\mathrm{p}<0.05$ is statistically significant, CD4: Cluster of differentiation 4 . In the data analysis, there was a significant moderate positive correlation ( $\mathrm{r}=0.472$ ) between CD 4 counts and $\mathrm{Hb}$ level $(\mathrm{p}<0.001)$ Hb: Hemoglobin

Table 5: The relationship between HIV clinical stages and $\mathrm{Hb}$ levels

\begin{tabular}{llc}
\hline Variable & \multicolumn{1}{l}{ HIV clinical stages } \\
\cline { 2 - 3 } & HIV $(\mathbf{n}=7)$ & AIDS $(\mathbf{n}=\mathbf{7 2})$ \\
\hline $\mathrm{Hb}$ & $9.5 \pm 0.8$ & $8.7 \pm 1.8$ \\
\hline $\mathrm{n}=79$, Data are expressed as mean \pm SD. SD: Standard deviation, HIV: Human \\
immunodeficieny virus, AIDS: Acquired immunodeficieny syndrome, Mean \\
of Hb levels among participants with HIV was 9.5 \pm 0.8 and in participants \\
with AIDS 8.7 \pm 1.8. The data analysis found a statistically significant mean \\
difference of Hb level among HIV and AIDS patients $(95 \%$ CI $0.04-1.64 ; \mathrm{p}<0.04)$, \\
Hb: Hemoglobin
\end{tabular}

A cross-sectional study of $\mathrm{Hb}$ measurements has consistently shown to play an important role in the basic management of HIV disease in West Africa $[24,25,28,43]$.

However, Alavi et al., 2009, found that there was no correlation between CD 4 counts and $\mathrm{Hb}$ levels $(r=0.451 ; p=0.056)$. This finding might be confounded by malnutrition and various socioeconomic factors, including a history living in prison and the use of injecting narcotics resulting in chronic anemia and low $\mathrm{Hb}$ levels. Moreover, three-quarters of the participants in their study were injecting drug users that misappropriately represent the true HIV situation $[26,44,45]$.

\section{The clinical staging of HIV infection with $\mathrm{Hb}$ levels}

HIV infection is caused a gradual loss of CD4 counts. Loss of CD4 counts and systemic immune activation are the major hallmarks of HIV infection. Systemic immune activation is characterized by massive production of pro-inflammatory cytokines $[14,17,19,23]$.

This study revealed a significant relationship between HIV clinical stages and $\mathrm{Hb}$ levels. The mean $\mathrm{Hb}$ level among HIV stage was 9.5 $\pm 0.8 \mathrm{~g} / \mathrm{dl}$ and the mean $\mathrm{Hb}$ among AIDS stage was lower: $8.7 \pm 1.8 \mathrm{~g} /$ dl. An average difference between HIV and AIDS patients was $0.8 \mathrm{~g} / \mathrm{dl}$ (95\% CI 0.04-1.64; $\mathrm{p}<0.04)$. This finding indicates that the severity of anemia increases with the progression of the HIV clinical stages.

Similar studies in India by Mathews et al., 2013, with 187 participants found a higher proportion of anemia among patients in AIDS than preAIDS clinical stages [27].

Alavi et al., 2009, in a cross-sectional study conducted in India with 306 participants, aimed to examine the incidence of anemia and its association with the WHO-based clinical staging and found that the proportion of anemia was higher among patients with HIV stage $4(33.3 \%)$ when compared with stage $1(1.2 \%)$. They also found that the severity of anemia increases with HIV clinical stages $(p=0.0001)$ [23]

\section{CONCLUSIONS}

Anemia is a common problem among HIV-infected patients, as a result of chronic inflammation or antiretroviral therapy. This study shows that the CD4 counts and HIV clinical stages correlate with $\mathrm{Hb}$ level among HIV patients with anemia. The severity of anemia correlates with low CD4 counts and advance HIV clinical stage.

\section{ACKNOWLEDGMENT}

The authors acknowledge all of the study participants for their cooperation, Director of Wangaya Hospital, Denpasar, Bali, Indonesia, all colleagues of Wangaya HIV Study Group who have supported this study.

\section{AUTHORS' CONTRIBUTIONS}

Ketut Suryana constructing an idea or hypothesis for research and manuscript, planning methodology to reach the conclusion, organizing and supervising the course of the project or the article, financial support, responsibility in data management, reporting, logical interpretation of the results, literature review, and construction of the whole format of the manuscript, and reviewing the article before submission (about spelling, grammar and its scientific aspects). Hamong Suharsono responsibility in logical interpretation and literature review. Gede Budiasa responsibility in the laboratory. Jarwa Antara responsibility in prepare and follow-up the participants, data management and reporting, literature review. Puji Astuti, Ida ayu Indah and Putri Stuti data collecting and reporting.

\section{CONFLICTS OF INTEREST}

There were no conflicts of interest among the authors. 


\section{REFERENCES}

1. Zon LI, Arkin C, Groopman JE. Haematologic manifestations of the human immune deficiency virus (HIV). Br J Haematol 1987;66:251-6.

2. Kulkarni MB, Bhalerao MM, Dube SP. Anemia in people living with HIV/AIDS: A cross sectional study from India. IOSR J Dent Med Sci 2015;14:2279-861.

3. Coyle TE. Hematologic complications of human immunodeficiency virus infection and the acquired immunodeficiency syndrome. Med Clin North Am 1997;81:449-70.

4. Volberding PA, Levine AM, Dieterich D, Mildvan D, Mitsuyasu R, Saag M, et al. Anemia in HIV infection: Clinical impact and evidencebased management strategies. Clin Infect Dis 2004;38:1454-63.

5. Kreuzer KA, Rockstroh JK, Jelkmann W, Theisen A, Spengler U, Sauerbruch $\mathrm{T}$, et al. Inadequate erythropoietin response to anaemia in HIV patients: Relationship to serum levels of tumour necrosis factor-alpha, interleukin-6 and their soluble receptors. Br J Haematol 1997;96:235-9.

6. World Health Organization. Worldwide Prevalence on Anaemia 19932005. Geneva: World Health Organization; 2008.

7. Hambleton J. Hematologic complications of HIV infection. Oncology (Williston Park) 1996;10:671-80.

8. Owiredu WK, Quaye L, Amidu N, Addai-Mensah O. Prevalence of anaemia and immunological markers among ghanaian HAART-naïve HIV-patients and those on haart. Afr Health Sci 2011;11:2-15.

9. Subbaraman R, Devaleenal B, Selvamuthu P, Yepthomi T, Solomon SS, Mayer $\mathrm{KH}$, et al. Factors associated with anaemia in HIV-infected individuals in southern india. Int J STD AIDS 2009;20:489-92.

10. Berhane K, Karim R, Cohen MH, Masri-Lavine L, Young M, Anastos K, et al. Impact of highly active antiretroviral therapy on anemia and relationship between anemia and survival in a large cohort of HIVinfected women: Women's interagency HIV study. J Acquir Immune Defic Syndr 2004;37:1245-52.

11. Sullivan PS, Hanson DL, Chu SY, Jones JL, Ward JW. Epidemiology of anemia in human immunodeficiency virus (HIV)-infected persons: Results from the multistate adult and adolescent spectrum of HIV disease surveillance project. Blood 1998;91:301-8.

12. Buskin SE, Sullivan PS. Anemia and its treatment and outcomes in persons infected with human immunodeficiency virus. Transfusion 2004:44:826-32.

13. Ssali F, Stöhr W, Munderi P, Reid A, Walker AS, Gibb DM, et al. Prevalence, incidence and predictors of severe anaemia with zidovudine-containing regimens in african adults with HIV infection within the DART trial. Antivir Ther 2006;11:741-9.

14. Moses A, Nelson J, Bagby GC Jr. The influence of human immunodeficiency virus-1 on hematopoiesis. Blood 1998;91:1479-95.

15. Koduri PR, Singa P, Nikolinakos P. Autoimmune hemolytic anemia in patients infected with human immunodeficiency virus-1. Am J Hematol 2002;70:174-6.

16. Belperio PS, Rhew DC. Prevalence and outcomes of anemia in individuals with human immunodeficiency virus: A systematic review of the literature. Am J Med 2004;116 Suppl 7A:27S-43S.

17. Bain BJ. Pathogenesis and pathophysiology of anemia in HIV infection. Curr Opin Hematol 1999;6:89-93.

18. Levine AM, Berhane K, Masri-Lavine L, Sanchez M, Young M, Augenbraun M, et al. Prevalence and correlates of anemia in a large cohort of HIV-infected women: Women's interagency HIV study. J Acquir Immune Defic Syndr 2001;26:28-35.

19. Semba RD, Shah N, Klein RS, Mayer KH, Schuman P, Vlahov D, et al. Prevalence and cumulative incidence of and risk factors for anemia in a multicenter cohort study of human immunodeficiency virus-infected and uninfected women. Clin Infect Dis 2002;34:260-6.

20. Richman DD, Fischl MA, Grieco MH, Gottlieb MS, Volberding PA, Laskin OL, et al. The toxicity of azidothymidine (AZT) in the treatment of patients with AIDS and AIDS-related complex. A double-blind, placebo-controlled trial. N Engl J Med 1987;317:192-7.

21. Volberding PA, Lagakos SW, Koch MA, Pettinelli C, Myers MW, Booth DK, et al.Zidovudine in asymptomatic human immunodeficiency virus infection. A controlled trial in persons with fewer than 500 CD4positive cells per cubic millimeter. The AIDS clinical trials group of the national institute of allergy and infectious diseases. N Engl J Med 1990;322:941-9.

22. Obirikorang $\mathrm{C}$, Yeboah FA. Blood haemoglobin measurement as a predictive indicator for the progression of HIV/AIDS in resourcelimited setting. J Biomed Sci 2009;16:102.

23. Paras Z, Waran M, Tyagi A. A study of prevalence of anemia among HIV patients and its correlation with clinical stage of AIDS, CD4 count and antiretroviral therapy. Int J Med Sci Clin Invent 2017;4:2538-43.

24. Moore RD, Keruly JC, Chaisson RE. Anemia and survival in HIV infection. J Acquir Immune Defic Syndr Hum Retrovirol 1998;19:29-33.

25. Ledru E, Diagbouga S, Meda N, Sanou PT, Dahourou H, Ledru S, et al. A proposal for basic management of HIV disease in West Africa: Use of clinical staging and haemogram data. Int J STD AIDS 1998;9:463-70.

26. Alavi SM, Ahmadi F, Farhadi M. Correlation between Total Lymphocyte Count, Hemoglobin, Hematocrit and CD4 Count in HIV/ AIDS Patients. Acta Medica Iranica 2009;47:1-4.

27. Mathews SE, Srivastava D, Balayadav R, Sharma A. Association of hematological profile of human immunodeficiency virus-positive patients with clinicoimmunologic stages of the disease. J Lab Physicians 2013;5:34-7.

28. Ako SE, Njunda LA, Akum EA, Benjamin PT, Eteneneg EJ, Bernard W, et al. Hematological related disorders and transfusion of HIV patients on highly active antiretroviral therapy (HARRT) in the South West Region of Cameroon: Hematological Monitory Parameters for HIV Follow-Up. J HIV Retrovirus 2018;4:1-9.

29. Kathuria S, Bagga PK, Malhotra S. Hematological manifestations in HIV infected patients and correlation with CD4 counts and anti retroviral therapy. Int J Contemp Med Res 2016;3:3495-8.

30. Thulasi RR, Manimaran D, Hemanathan G, Tameem A, Radha S. Hematological abnormalities in HIV infected individuals in correlation to CD4 counts and ART status. Asian J Med Sci 2016;7:14-8.

31. Mehta S, Jutur S, Gautam. Hematological manifestations of HIV/ AIDS. Med Update 2011:483-90. Available from: https://www. semanticscholar.org/paper/Hematologic-Manifestations-of-HIV-\%2FAIDS-Mehta-Jutur/4560ee231345f13a0c86e63616848a38a228f8ec

32. Kasthuri AS, Sharma S, Kar PK. A Study of Hematological manifestations of HIV infection. Indian J Sex Transm Dis 2006;27:9-16.

33. De Santis GC, Brunetta DM, Vilar FC, Brandão RA, de Albernaz Muniz RZ, de Lima GM, et al. Hematological abnormalities in HIVinfected patients. Int J Infect Dis 2011;15:e808-11.

34. Kumar MB, Thippeswamy T, Shankar R, Prathima C. Hematological abnormalities in ealry and advanced HIV infection patients. Int J Sci Stud 2016:3:1-11.

35. Dikshit B, Wanchu A, Sachdeva RK, Sharma A, Das R. Profile of hematological abnormalities of Indian HIV infected individuals. BMC Blood Disord 2009;9:5.

36. Addis Z, Yitayew G, Tachebele B. Prevalence of some hematological abnormalities among HIV positive patients on their first visit to a tertiary health instituion in Ethiophia; a cross sectional study. Int Blood Res Rev 2014;2:270-8.

37. Munyazesa E, Emile I, Multimura E, Hoover DR, Shi Q, McGinn AP, et al. Assessment of haematological parameters in HIV-infected and uninfected Rwandan women: A cross-sectional study. BMJ Open 2012;2:1-8.

38. Opie J. Haematological complications of HIV infection. S Afr Med J 2012;102:465-8

39. Afari SK, Blay EA. Prevalence of hametological and serum biochemical abnormalities in HIV infected patients in Ghana, before and after Antiretroviral Therapy. Int J Virol AIDS 2018;5:1-10.

40. Ezeonwu BU, Ikefuna AN, Oguonu T, Okafor HU. Prevalence of hematological abnormalities and malnutrition in HIV-infected under five children in Enugu. Niger J Clin Pract 2014;17:303-8.

41. Shruthi MS, Elavarasan T, Puvitha RD. Hematological profile of people living with HIV infection in government Dharmapuri medical college, Dharmapuri. Int Arch Integr Med 2017;4:228-33.

42. Parinitha S, Kulkarni M. Haematological changes in HIV infection with correlation to CD4 cell count. Australas Med J 2012;5:157-62.

43. Robinson O, Obianime AW, Aprioku J, Tamuno I. Immunological and hematological profile of HIV patients on anti-retroviral therapy in Port Harcourt Rivers State, Nigeria. Int Blood Res Rev 2017;7:1-12.

44. Redig AJ, Berliner N. Pathogenesis and clinical implications of HIVrelated anemia in 2013. Hematology Am Soc Hematol Educ Program 2013;2013:377-81

45. Assefa M, Abegaz WE, Shewamare A, Medhin G, Belay M. Prevalence and correlates of anemia among HIV infected patients on highly active anti-retroviral therapy at Zewditu memorial hospital, Ethiopia. BMC Hematol 2015;15:6.

46. Dinakar KR, Narendranath S, Vaneet A, Reshma SR, Somashekar HS, Keerthisagar JL. Changes in the CD4 counts, hemoglobin and weight in patients with HIV alone and HIV TB co-infection. Asian J Pharm Clin Res 2014; 7 Suppl 2:35-8.

47. Bhatnagar S, Sharma H, Sharma VK. Study of adverse effects of anti retroviral therapy in HIV naïve patients and their association with CD4 cell count. Asian J Pharm Clin Res 2013;6 Suppl 5:122-3. 